\title{
The experimental study of the influence of soil microorganisms - consorts of diazotrophs on the growth and development of Triticum aestivum $\mathrm{L}$.
}

\author{
O. I. Vinnikova*, D. V. Glushach \\ https://doi.org/10.31174/SEND-NT2018-157VI17-09 \\ V. N. Karazin Kharkiv National University \\ *Corresponding author. E-mail: o.i.vinnikova@karazin.ua
}

Paper received 26.01.18; Accepted for publication 02.02.18.

\begin{abstract}
The study explored experimentally the influence of suspensions of soil microorganisms or multicomponent preparation "Baikal" on the vegetative growth and development of wheat plants. The suspensions containing just a few soil microbiota species, which are the consortia of the diazotroph Azosirillum brasilense, were able to produce a meaningful positive effect on the test-plant morphometric parameters and on the concentration of sugars in wheat leaves. Also, the heterogeneous impact (stimulation or delay) on wheat seeds germination was found after their inoculation with various combinations of suspensions of microorganisms. The results obtained can be used for the development of preparations aimed at the regulation of the intensity of grain germination in hard weather conditions.
\end{abstract}

Keywords: Azosirillum brasilense, consorting microorganisms, Triticum aestivum, growth and development of plants.

Introduction. The quality of agricultural soils gradually declines year by year: their depletion in certain elements is regularly detected. The deficit of nitrogen, phosphorus and iron compounds, accessible for plants, negatively affects the yield and quality of the crop that undoubtedly results into economic losses. Also the Earth human population increases in geometric progression, while the accumulation of resources follows the arithmetic rule, thus the problem of the serious deficiency of nutrition becomes crucial. One of possible ways to overcome it includes an active application of various chemical fertilizers on farming lands. This method is far not the best choice, regarding the balance of its low efficiency to high ecological damage. However, there is a good alternative for chemical agents. These are biological fertilizers, which are based on active strains of microorganisms and show nitrogen fixing, phosphate mobilizing and growth stimulating properties $[1,8,13]$.

The PGPR-bacteria are the only group, which can positively modify plants' growth and development in their natural environment, by providing inorganic ingredients (nitrogen, phosphorus, etc.) or by synthesizing phytohormones and other biologically active substances. These bacteria also can influence the plant rooting and increase their growth rate and general productivity, and also can prevent the expansion of plant pathogens $[9,11]$. This group of bacteria has known specificity towards higher plants species. For example, nitrogen fixing Azospirillum brasilense tends to populate the root system of wheat [10]. However, these microorganisms don't exist in the soil alone; they are surrounded by other representatives of the soil biota, which can form consortia together with diazotrophs. If active strains are introduced into the soil, then a wide spectrum of relationships occurs between them and the indigenous microflora, ranging from neutrality to antagonism. Thus, before any biological fertilizers start being applied in agricultural practice, it is absolutely necessary to investigate a potential influence of inoculation of plant seeds by these active strains in the presence of other soil organisms or their metabolites in well controlled experimental conditions, in order to evaluate and to prevent undesirable ecological effects.

Study objectives. The aim of present study was to assess experimentally the influence of the obligate diazotrophic microorganism Azasphirillum brasilense and its microbiotic consortium on the physiological and biochemical parameters of wheat Triticum aestivum L.

Materials and Methods. The list of microbiota species used in this research includes: soil bacteria Azospirillum brasilense corrig. Tarrand et al., Bacillus cereus Frankland and Frankland, B. mesentericus Toa; soil micromycetes - Tricho- derma viride Pers., Fusarium oxysporum Schltdl., Penicillium notatum Westling, Aspergillus niger van Tiegh; soil algae - Tetracystis sp., Bracteacoccus sp.; wheat Triticum aestivum L. varieties of Gordovita. These microorganisms have been the most often observed as members of consortia of the diazotroph A. brasilense, which is a representative of PGPRbacteria associated with wheat root system [2, 3, 10]. Microorganisms and plant seeds for the experiment were obtained from the relevant collections of the Department of Physiology and Biochemistry of Plants and Microorganisms of V.N. Karazin National University. Algae species were extracted from the soil by the glass fouling method [4] ex tempore before the start of the experiment. All microorganisms were extracted from the upper soil layers in local agrocenoses (mainly, wheat fields).

For the experiment the microorganisms were cultured using appropriate media: MDA for Azospirillum [14], MPB for bacteria, mash agar - for micromycetes [7], and Bold's medium - for algae [12]. Also, sterilized (autoclaved) black soil, collected on the field after growing wheat, was used in the experiment. The vegetation experiment was set up using $1 \mathrm{ml}$ of a suspension containing $1 \times 10^{5}$ objects $/ \mathrm{ml}$; objects were cells of microorganisms or conidia of micromycetes. The sham treated control was wheat seeds kept in the sterile, distilled water. Wheat seeds were sterilized by sodium hypochlorite (commercially available solution "Bilyzna", $92.5 \%$ of active chlorine), washed in sterile distilled water, inoculated with a suspension of microorganisms and seeded into vessels containing $250 \mathrm{~g}$ soil. The plants were grown in a constant climate chamber at temperature $+22 \pm 1^{\circ} \mathrm{C}$ under artificial illumination of 16 hours per day under $2000 \mathrm{~lx}$ lamps. The experiment lasted for 21 days and was conducted in two replicates. The soil in the containers was periodically moistened with a settled tap water. During the experiment the synchronism of wheat seedlings appearance was evaluated. On the day 21 the measurements were done for the length and the mass of the aboveground and underground parts, and for the content of sugars in the leaves using Shvetsov and Lukyanenko method [5].

In one of the experimental settings an industrially produced and commercially available multicomponent biofertilizer "Baikal" ("EM Centre Ltd.", Ulan-Ude, Russia) was used.

According to the manufacturer's description, "Baikal" includes about 60 species of soil microorganisms. The contents of microorganism communities, modeled in different experimental sets, are presented in Table 1. For the measured parameters mean values and relevant standard error were estimated and presented in the Results. The statistical difference 
between experimental points was assessed by Student's $t$-test [6].

Table 1. The contents of microbiota groups modeled in the experiment

\begin{tabular}{|c|c|}
\hline $\begin{array}{l}\text { Sets of the } \\
\text { experiment }\end{array}$ & Treatment conditions, microorganisms \\
\hline Control & Seeds were kept in sterile distilled water \\
\hline 1 & $\begin{array}{l}\text { Biological fertilizer "Baikal"; seeds treated according } \\
\text { to manufacturer's instructions }\end{array}$ \\
\hline 2 & Azosirillum brasilense \\
\hline 3 & $\begin{array}{l}\text { A. brasilense, Bacillus cereus, B. mesentericus, } \\
\text { Tetracystis sp., Bracteacoccus } s p .\end{array}$ \\
\hline 4 & $\begin{array}{l}\text { A. brasilense, Tetracystis sp, Bracteacoccus sp, } \\
\text { Trichoderma viride, Fusarium oxysporum, Penicillium } \\
\text { notatum, Aspergillus niger }\end{array}$ \\
\hline 5 & Tetracystis sp., Bracteacoccus $s p$. \\
\hline 6 & $\begin{array}{l}\text { B. } \quad \text { cereus, B. } \quad \text { mesentericus, } \\
\text { Bracteacoccus sp. }\end{array}$ \\
\hline 7 & $\begin{array}{l}\text { Tr. viride, } F . \text { oxysporum, } P . \text { notatum, A. niger, } \\
\text { Tetracystis sp., Bracteacoccus sp. }\end{array}$ \\
\hline 8 & Mixed suspension of all listed microorganisms \\
\hline
\end{tabular}

Results and discussion. Experimental data on the influence of inoculation of wheat seeds by suspensions of microorganisms or bio-fertilizer are presented in Figure 1. It was found that the seeds treated by suspensions of soil algae alone, algae plus bacteria or all microorganisms mixed together showed the most successful germination. It can be suggested that these particular microorganisms excrete some biologically active substances (e.g., phytohormones) that stimulate germination of seeds.

Table 2 contain the results of measurements of the mass of above- and underground parts of wheat plants on day 21 of the vegetative experiment. The stimulation of growth and development of vegetative mass of wheat plants occurred after seeds treatment with soil algae and bio-fertilizer "Baikal".

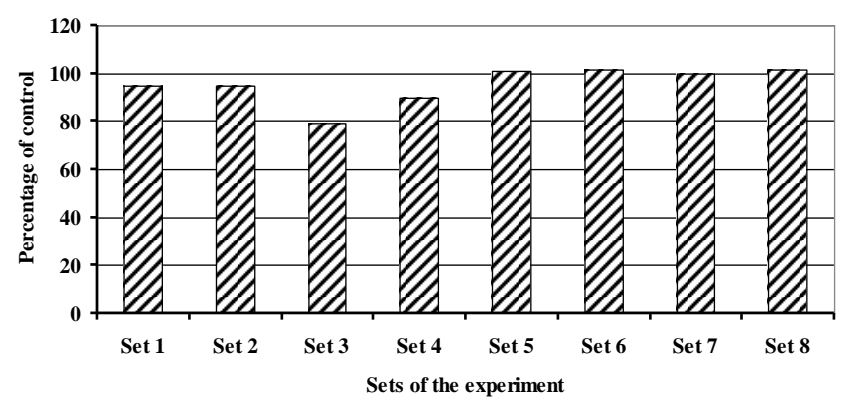

Figure 1. The germination of wheat seeds (percentage of the control) after their treatment with various suspensions of microorganisms.

The values of plants vegetation mass after seeds treatment with a mixed suspension of bacteria, algae and A. brasilense appeared to be the lowest among experimental points including control.

However, in this particular experiment a positive effect on the development of the root system of plants was observed (Table 2). The most negative impact on wheat roots occurred in the experiment with suspensions of micromycetes and algae. Probably, in this situation micromicetes and algae caused a considerable acidification of the culture medium [4, 7], that suppressed the root growth.

The averaged results of measuring the length of the above-ground part are given on Figure 2. At all experimental points the microbiota produced similar effect, except the abnormally low growth in the set treated with A. brasilense alone. Some positive, but statistically insignificant influence of the seeds treatment on the enlargement of the aboveground part was observed in cases of the bio-fertilizer and a suspension of soil algae.

Table 2. The mass of the above- and underground part of wheat plants vegetated after inoculation of the seeds with the suspensions of microorganisms

\begin{tabular}{|c|c|c|}
\hline $\begin{array}{c}\text { Sets of the } \\
\text { experiment }\end{array}$ & $\begin{array}{c}\text { Mass of the aboveground } \\
\text { part of plants, } \mathrm{g}\end{array}$ & $\begin{array}{c}\text { Mass of the underground } \\
\text { part of plants, } \mathrm{g}\end{array}$ \\
\hline Control & $0,243 \pm 0,016$ & $0,073 \pm 0,018$ \\
\hline 1 & $0,250 \pm 0,006$ & $0,091 \pm 0,009$ \\
\hline 2 & $0,217 \pm 0,013$ & $0,071 \pm 0,033$ \\
\hline 3 & $0,205 \pm 0,039$ & $0,086 \pm 0,034$ \\
\hline 4 & $0,228 \pm 0,031$ & $0,077 \pm 0,001$ \\
\hline 5 & $0,256 \pm 0,045$ & $0,085 \pm 0,007$ \\
\hline 6 & $0,212 \pm 0,010$ & $0,079 \pm 0,001$ \\
\hline 7 & $0,212 \pm 0,007$ & $0,063 \pm 0,006$ \\
\hline 8 & $0,234 \pm 0,028$ & $0,082 \pm 0,005$ \\
\hline
\end{tabular}

The patterns of the concentration of sugars in plant leaves on different experimental points are shown on Figure 3. It should be noted that this parameter appeared to be higher after any treatment compared to that in control. Maximum levels of sugars were observed in the experimental sets with a mixed suspension of all microorganisms and also with "Baikal".

Figure 4 represents data on total sugar contents in wheat leaves. Naturally, the increase above control was also detected in treated plants, reaching the maximum in the set with the inoculation of seeds with a mixture of $A$. brasilense and soil algae.

To some extent this finding can be explained by known diazotrophic activity of Azospirillum. These species can enhance a photosynthetic activity of plants due to the increase of the protein content, in particular the Rubisco enzyme, that results into higher contents of sugars [15].

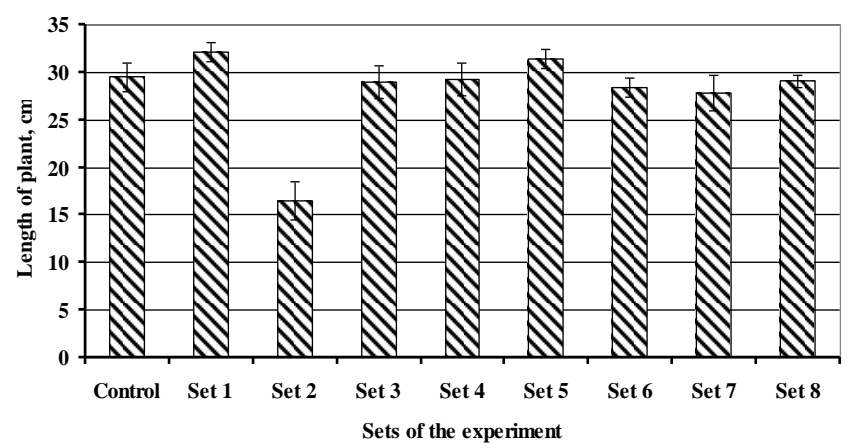

Figure 2. Mean length of the above-ground part of the wheat plants, grown from seeds inoculated with the suspensions of microorganisms.

Conclusions. The experiment based on treating wheat seeds with various microorganisms showed a meaningful heterogeneity of that impact on the growth and development of test-plants. Bacteria alone, algae alone and micromycetes coupled to algae stimulated wheat germination. By contrast, Azospirillum with algae slowed down the germination. These effects can be used for the development of drugs, aimed at the regulation of the intensity of grain germination in hard weather conditions. Also the results showed the positive influence of soil algae alone on the mean vegetation mass, while the Azospirillum plus algae acted in the opposite manner. However, Azospirillum species alone increased significantly the amount of sugar in plants. This ability can be applied for prevention of plant falling, and what is important it can be achieved with no inhibition, but with an intensification of the carbohydrate metabolism. 


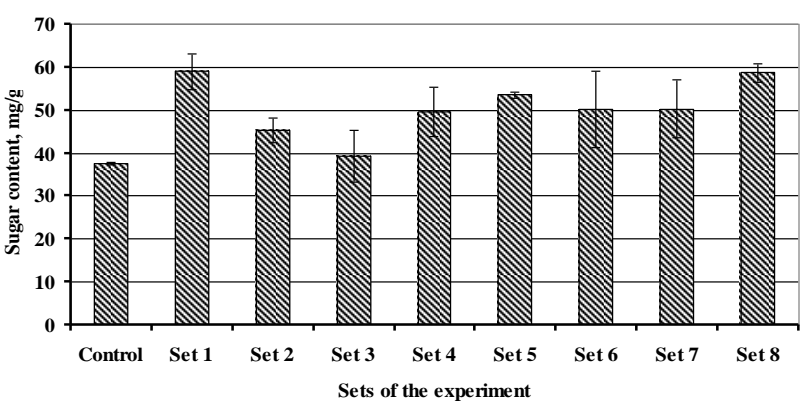

Figure 3. The concentration of reducing sugars in leaves of wheat grown from seeds, inoculated with different suspensions of microorganisms.

A special experimental set in the present study was based on the usage of commercially available bio-fertilizer "Baikal", which is a multicomponent mixture (about 60 species) of microorganisms.

ЛИТЕР

1. Алещенкова 3.М., Сафронова Г.В., Мельникова Н.В., Есенбаева А. Е., Тен О.А. Азотфиксирующие и фосфатмобилизирующие бактерии для стимуляции роста сельскохозяйственніх культур // Вестник Башкирского университета. Серия « Биология». 2015. - №1. - C. 82- 86.

2. Асатурова А.М. Изучение влияния бактеризации семян на рост и развитие растений озимой пшеницы // Научный журнал КубГАУ. - 2013. - №85(01). - С. 1-14.

3. Белюченко И.С., Пономарева Ю.В. Грибные консорты озимой пшеницы в степной зоне краснодарского края // Экологический вестник Северного Кавказа.-2005.-Т.1, №2.-С. 128-137.

4. Голлербах М.М., Штина Э.А. Почвенные водоросли. - Л.: Наука, 1969. - 228 с.

5. Ермаков А.И. Методы биохимического исследования растений. - Л.: Колос, 1972. $-456 \mathrm{c}$

6. Лакин Г.Ф. Биометрия. - М.: Высш. школа, 1990. - 350 с.

7. Методы экспериментальной микологии. - Киев: Наук. думка, 1982. $-550 \mathrm{c}$.

8. Моргун В.В., Коць С.Я., Кириченко Е.В. Ростстимулирующие ризобактерии и их практическое применение//Физиология и биохимия культурных растений.-2009.-Т. 41, № 3.-С.187-207.

9. Феоктистова Н.В., Марданова А.М., Хадиева Г.Ф., Шарипова M.Р. Ризосферные бактерии // Ученые записки Казанского Университета. Серия «Естественные Науки». - 2016. - Т.158, кн.2. - С. 207-224.

\section{REFERENCES}

1. Aleshenkova Z.H., Safronova N.V., Melnikova N.V., Yesnbaeva A.E., Ten O.A. Nitrogen-fixing and Phosphate-mobilizing bacteria promoting growth of cultivars // Herald of the Bashkir University. series "Biology". - 2015. - №1. - P. 82-86.

2. Asaturova A.M. Study of the influence bacterization seed on growth and development of fall wheat // Science Journal KubGAU. 2013. - №85(01). - C. 1-14.

3. Belyuchenko I.S. Ponomareva Yu.V. Fungi consourts of winter wheat in the steppe zone of the Krasnodar Region // Ecological Herald of the North Caucasus. - 2005. - T.1, №2. - C. 128-137.

4. Gollerbach MM, Shtina E.A. Soil algae.- L.: Nauka,1969. -228 p.

5. Yermakov A.I. Methods of biochemical research of plants. $-\mathrm{L}$.: Kolos, 1972. - 456 p.

6. Lakin G.F. The Biometrics. - M.: Vysh. shkola, 1990. - 350 p.

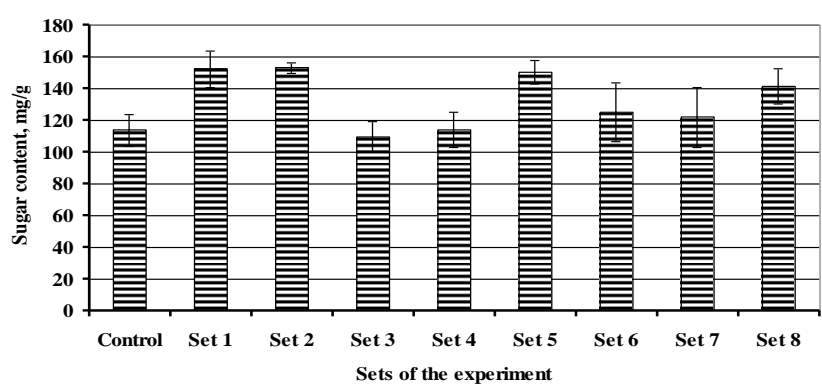

Figure 4. Total sugar content sugars in leaves of wheat grown from seeds, inoculated with different suspensions of microorganisms.

However, plants treated with this preparation didn't show much difference from plants in other experimental sets for nearly all measured parameters. Therefore, a significant advantage of multicomponent preparations for seed treatment in trying to increase the crop yields remains questioned, because of high possibility of the mutually opposed action of different components included into such a mixture.

10. Филипьечева Ю.А. Эколого-физиологические и серологические свойства бактерий рода Azospirillum различных растительно-бактериальных сообществ. - Автореф.дис...канд.биол.наук. - Саратов, 2011. - 22 с.

11. Шапошников А.И., Белимов А.А., Кравченко Л.В., Виванко Д.М. Взаимодействие ризосферных бактерий с растениями: механизмы образования и факторы эффективности ассоциативных симбиозов (обзор) // Сельскохозяйственная биология. -2011. - № 3. - C. 16-22.

12. Bischoff H.W., Bold H.C. Phycological studies. IV. Some soil algae from Enchanted Rock and related algae species // Univ. of Texas Publ. - 1963. - № 6318. - P. 1-95.

13. Perrig D., Boiero M. L., Masciarelli O. A., Penna C., Ruiz O. A., Cassán F. D., Luna M. V. Plant-growth-promoting compounds produced by two agronomically important strains of Azospirillum brasilense, and implications for inoculant formulation // Applied Microbial And Cell Physiology. - 2007. - Vol. 75. - P. 1143-1150.

14. Sadasivan L., Neyra C.A. Flocculation in Azospirillum brasilense and Azospirillum lipoferum: exopolysaccharides and cyst formation // J. Bacteriol. - 1985. - Vol. 163, №2. -P. 716-723.

15. Stancheva I. et al. Effects of inoculation with Azospirillum brasilense on photosynthetic enzyme activities and grain yield in maize //Agronomie. - 1992. - T. 12, №. 4. - P. 319-324.

7. Methods in experimental mycology.-Kiev: Nauk. dumka, 1982.-550p.

8. Morgun V.V., Kots S.Ya., Kyrychenko O.V. Growth promoting Rhizobacteria and their use on practice // Physiology and biochemistry of cultivated plants. - 2009. - T. 41, № 3. - C. 187-207.

9. Feoktistova N.V., Mardanova A.M., Hadieva G.F., Sharipova M.R. Rhizosphere bacteria // Uchenye Zapiski KazanskogoUniversiteta. Seriya «Estestvennye Nauki». - 2016, Vol.158, №2. - P. 207-224.

10. Filipecheva Yu.A. Ecology-physiological and serological properties of bacteria of the genus Azospirillum of various plantbacteria communities.-PhD Thesis (Biology).-Saratov, 2011.-22 p.

11. Shaposhnikov A.I., Belimov A.A., Kravchenko L.V., Vivanco J.M. Interaction of rhizosphere bacteria with plants: mechanisms of formation and factors of efficiency in associative symbiosis (review) // Agricultural Biology. - 2011. - №3. - P. 16-22

Влияниепочвенных микроорганизмов-консортов диазотрофов на рост и развитие Triticum aestivum L. в условиях эксперимента

\section{О. И. Винникова, Д. В. Глушач}

Аннотация. В работе исследовали влияние суспензий почвенных микроорганизмов и поликомпонентного препарата “Байкал” на рост и развитие растений пшеницы в условиях вегетационного опыта. Оказалось, что малокомпонентные композиции из почвенных микроорганизмов - консортов диазотрофа Azosirillum brasilense могут оказывать позитивное влияние на морфометрические показатели и содержание сахаров в листьях пшеницы. Также был установлен разнонаправленный эффект (стимуляция или задержка) по прорастанию семян пшеницы при их инокуляции разными сочетаниями суспензий микроорганизмов. Полученные результаты можно использовать при создании биопрепаратов, действие которых направлено на регуляцию интенсивности прорастания зерновых культур при сложных погодных условиях.

Ключевые слова: Azosirillum brasilense, микроорганизмы-консорты, Triticuт аеstivuт, рост и развитие растений. 